TAPROBANICA, ISSN 1800-427X. April, 2013. Vol. 05, No. 01: pp. 85-86.

(C) Taprobanica Private Limited, 146, Kendalanda, Homagama, Sri Lanka.

www.taprobanica.org

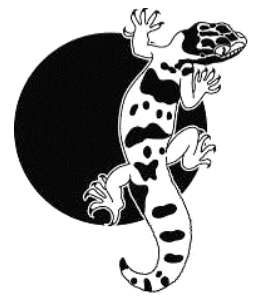

\section{The small flying squirrel (Petinomys fuscocapillus) observed after 78 years in Sri Lanka}

Petinomys fuscocapillus (Kelaart, 1852) is one of two nocturnal Squirrels found in Sri Lanka (Phillips, 1980), and the distribution of the species is only known through a few possible occurrences and museum specimens which were collected nearly hundred years ago. The species was considered to be extinct in India until 1989, when it was rediscovered in a coconut grove in Kerala state, India (Kurup, 1989). In Sri Lanka it was reported by Phillips (1935) from the wet and intermediate zones of the island, and subsequently the occurrence of this species was confirmed by camera trap by Jayasekara et al. (2007) in Sinharaja tropical rain forest. Here we report the first physical examination of this species in Sri Lanka after 78 years, and we publish the first colorphotographs. The authors obtained a direct sighting of the Small flying squirrel in the Knuckles Forest Reserve ( $7^{\circ} 32^{\prime} 55.0^{\prime \prime} \mathrm{N}$ and $\left.80^{\circ} 47^{\prime} 45.9^{\prime \prime} \mathrm{E}\right)$ at an elevation of $522 \mathrm{~m}$ asl.

An individual of Small flying squirrel (Petinomys fuscocapillus) was observed (Fig. $1 \mathrm{~A}, \mathrm{~B})$ at $2130 \mathrm{hr}$ on 26 January of 2013, on a tree $9 \mathrm{~m}$ above ground level, by the side of the Laggala - Illukkubura road. Photographs were taken using a Canon 550 D fitted with a 100 $400 \mathrm{~mm}$ Canon zoom lens. The species identification was confirmed using the Manual of Mammals of Sri Lanka by Phillips (1980). To confirm our identification, specimens of Petinomys fuscocapillus and Petaurista phillipinensis were examined in the National Museum of Sri Lanka.

The observed forest habitat is a well-developed semi-evergreen forest. It is a mature forest which has a continuous canopy; hence the forest interior is dark. Approximate canopy cover of this habitat is $80 \%$. Height of the forest profile of this location is around $25 \mathrm{~m}$.
We observed the animal for approximately 30 min. Its locomotion is slow and deliberate, and the tail is stretched out; when stationary, including when feeding, the tail is held above the body. It was very selective in feeding; we observed it to eat only the tender part of a shoot, and the leaves and the rest of the densely grown climber were discarded. It was not observed gliding; when moving about it stuck to the canopy and used branches of the adjoining trees, perhaps due to the moderately developed membrane of this species. More observations would be needed before coming to conclusions about its normal locomotion.

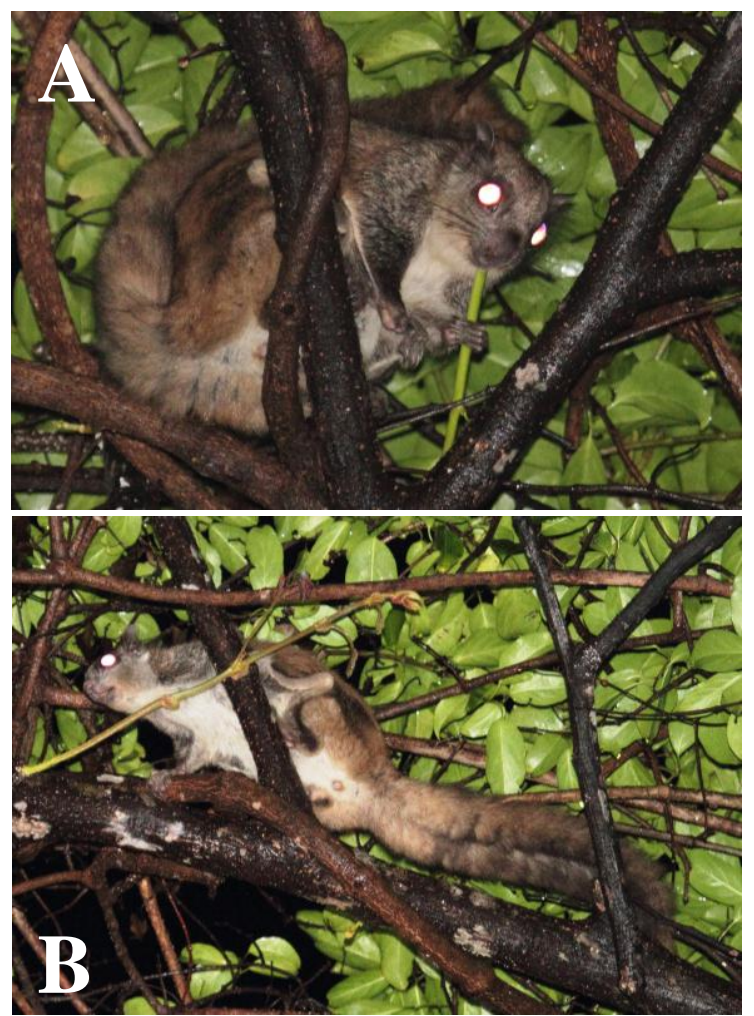

Figure 1A\&B: Petinomys fuscocapillus observed on 26 January 2013.

\section{Acknowledgements}

The authors extend their sincere gratitude to Gamini at Ranamure village of Mathale for tireless hours in the field, Gayan Edirisinghe for sharing literature, and the Forest department and Department of Wildlife Conservation in Sri 
Lanka for numerous support. Finally we would like to thank Colin Groves (Australian National University) for editing the manuscript.

\section{Literature Cited}

Jayasekara, P., U. R. Weerasinghe, S. Wijesundara and S. Takatsuki, 2007. Identifying diurnal and nocturnal frugivores in the terrestrial and arboreal layers of a tropical rain forest in Sri Lanka. Ecotropica, 13: 7-15.

Kelaart, E. F., 1852. Prodromus Faunae Zeylanicae: Being contributions to the Zoology of Ceylon, Kandy: 197.

Kurup, G. U., 1989. Rediscovery of small Travancore Flying Squirrel. Oryx, 23: 2-3.

Phillips, W. W. A., 1935. Manual of the Mammals of Ceylon. Ceylon Journal of Science, Dulau and Company, London: 371.

Phillip, W. W. A., 1980. Manual of the mammals of Sri Lanka, Part 2. Wildlife and nature protection society of Sri Lanka, Colombo, Sri Lanka: 267.

Submitted: 2 April 2013, Accepted: 20 April 2013 Sectional Editor: Colin P. Groves

R. P. Nanayakkara ${ }^{1}$, N. Vishvanath ${ }^{1,2} \&$

T. G. T. Kusuminda ${ }^{1,3}$

${ }^{1}$ Biodiversity Education \& Research, Pitakotte, Sri Lanka.

${ }^{2}$ Young Biologists' Association of Sri Lanka, National Museum of Sri Lanka.

${ }^{3}$ Department of Export Agriculture, Faculty of Agricultural Sciences, Sabaragamuwa University of Sri Lanka. E-mail: t.kusuminda@gmail.com 